\title{
Czy u kobiet obarczonych wysokim ryzykiem raka piersi należy wykonywać profilaktyczną mastektomię? Głos na NIE
}

\author{
Sylwia Grodecka-Gazdecka
}

\section{Prophylactic mastectomy should not be used in high risk breast cancer patients}

Profilaktyczna mastektomia jest procedurą operacyjną, której celem powinna być eliminacja ryzyka zachorowania na raka piersi. Celowo używam sformułowania „powinna być", ponieważ jednym z argumentów na "nie" będzie fakt, iż procedura ta jedynie zmniejsza, a nie znosi całkowicie powyższego ryzyka.

Historycznie operacja usunięcia miąższu piersi wykonywana była u kobiet z obciążonym wywiadem rodzinnym, bolesnością piersi, kancerofobią lub wywiadem związanym z licznymi biopsjami piersi (zwłaszcza ze stwierdzonymi zmianami proliferacyjnymi). Dzisiaj mastektomia profilaktyczna jest elementem chirurgii zorientowanej molekularnie, której celem jest zmniejszenie umieralności wywoływanej przez genetycznie uwarunkowaną chorobę nowotworową.

W praktyce adresowana jest do kobiet z grupy najwyższego i wysokiego ryzyka zachorowania na raka piersi i polega na amputacji obu piersi u kobiet bez objawów nowotworu lub piersi przeciwległej u chorej na raka. Zakres wykonywanych operacji obejmuje amputację prostą lub podskórną, z rekonstrukcją lub bez rekonstrukcji [1].

Do grupy najwyższego ryzyka (obarczonego ponad 10-krotnie wyższym prawdopodobieństwem zachorowania w porównaniu z ogólną populacją) zaliczane są kobiety, u których:

- rozpoznano patogenną mutację w genach BRCA1 lub BRCA2,

- u krewnych pierwszego i drugiego stopnia występuje 3 lub więcej zachorowań na raka piersi i raka jajnika (włącznie z probantką),

- odnotowano zachorowania na synchroniczne lub metachroniczne raki piersi i jajnika.
Nosicielstwo germinalnych mutacji genów supresorowych BRCA1 i BRCA2 odpowiada za kilka procent zachorowań na raka piersi. Jednocześnie dla nosicielki mutacji genu BRCA1 lub BRCA2 ryzyko zachorowania na raka piersi szacowane jest na 60-80\%, a dla raka jajnika - na 16-40\%. Oznacza to, że $20-40 \%$ nosicielek mutacji BRCA1 nie zachoruje na raka piersi, a 60-84\% nie zachoruje na raka jajnika.

Do grupy wysokiego ryzyka zachorowania na raka piersi zaliczane są kobiety bez mutacji $B R C A$ 1/2, u których w wywiadzie rozpoznano: 2 zachorowania u krewnych I lub || stopnia przed 50 rokiem życia lub 3 zachorowania u krewnych w dowolnym wieku [2]. Najwyższe lub wysokie ryzyko zachorowania zdefiniowane według powyższych kryteriów występuje w Polsce u 12\% chorych na raka piersi, czyli u 0,5\% kobiet w całej populacji.

Profilaktyczna mastektomia obniża, co prawda, ryzyko zachorowania na raka piersi, ale - jak zauważają autorzy wielu publikacji — powoduje istotny wzrost psychosomatycznych konsekwencji takiej decyzji [3-6]. Współczesny paradoks polega na tym, że lokoregionalne leczenie inwazyjnego raka piersi może być ograniczone do procedury zachowującej narząd - BCT (breast conserving therapy), a w profilaktyce rekomenduje się mastektomię. Tymczasem, mimo niekwestionowanych korzyści, jakimi są: obniżenie ryzyka zachorowania i zmniejszenie niepokoju związanego z poczuciem zagrożenia zachorowaniem, profilaktyczna mastektomia powoduje typowe dla działań chirurgicznych ryzyko powikłań wczesnych, jak i odległych konsekwencji przebytego leczenia. Do powikłań wczesnych zaliczane są: krwawienia, zakażenie rany, przewlekłe gromadzenie płynu pod blizną, opóźnienie gojenia czy deformacje blizny [7].

Katedra i Klinika Onkologii

Uniwersytet Medyczny im. Karola Marcinkowskiego w Poznaniu

Wystąpienie podczas II Konferencji Naukowej czasopisma Nowotwory „Debaty onkologiczne” 11-12 kwietnia 2014 roku 
Dużo większe znaczenie mają konsekwencje odległe. Do najważniejszych należy trwały i nieodwracalny charakter przebytej operacji oraz brak 100-procentowej gwarancji, że nowotwór nie wystąpi, ponieważ mimo największej staranności chirurga może nie być warunków do doszczętnego usunięcia miąższu, a nowotwór potrafi rozwinąć się nawet w najmniejszej objętości pozostawionej tkanki. Innymi odległymi efektami profilaktycznej mastektomii są między innymi: potrzeba rekonstrukcji piersi, zaburzenia czucia, utrata zdolności karmienia piersią, obawy lub depresja spowodowana zmianą wyglądu, wpływ na seksualność kobiety [3, 5].

Do najsilniejszych argumentów przeciw rutynowemu wykonywaniu profilaktycznej mastektomii u kobiet z grupy wysokiego ryzyka zachorowania na raka piersi należą:

1. Brak testu określającego, która z kobiet z grupy wysokiego ryzyka zachoruje na raka piersi, jeśli nie podda się profilaktycznej mastektomii (co oznacza, że wiele tych operacji wykonanych jest niepotrzebnie).

2. Brak randomizowanych badań klinicznych. Przeprowadzenie idealnego badania randomizowanego jest trudne do zrealizowania, ponieważ powinno ono porównywać grupę kobiet poddanych profilaktycznej mastektomii z grupą kobiet o identycznym ryzyku, poddanych ścisłej obserwacji (ewentualnie chemoprewencji), a czas obserwacji co do efektywności procedur powinien wynosić od 10 do 20 lat.

3. Fakt istnienia innych rodzajów profilaktyki, w tym:

- ścisłej kontroli z częstymi badaniami fizykalnymi i obrazowymi,

- i/lub ooforektomii,

- chemoprewencji tamoksyfenem lub inhibitorami aromatazy.

Zalecany przez Polską Unię Onkologii [2] schemat badań kontrolnych w grupie najwyższego i wysokiego ryzyka zachorowania na raka piersi i jajnika to:

— od 18. r. ż.: samokontrola piersi raz w miesiącu, po miesiączce,

— od 25. r.z. lub 10 lat przed najmłodszym zachorowaniem w rodzinie - co 6 miesięcy: badanie piersi przez lekarza, badania obrazowe: MR u kobiet poniżej 30. r.ż. lub w przypadku niejednoznacznego wyniku MMG; MMG na przemian z MR u kobiet powyżej 30. r.ż.; USG piersi jako badanie uzupełniające co 12 miesięcy,

- od 35. r.ż. lub 10 lat przed ostatnim zachorowaniem w rodzinie - co 6 miesięcy: USG dopochwowa i oznaczanie stężenia Ca125 (między 5. a 10. dniem cyklu u kobiet przed menopauzą),

- coroczne badanie ginekologiczne; co 3 lata badanie cytologiczne,

- przestrzeganie zaleceń dietetycznych w celu przeciwdziałania otyłości oraz systematyczna aktywność fizyczna.
W rodzinach najwyższego ryzyka zachorowania, w przypadku udokumentowanego nosicielstwa mutacji genu $B R C A 1 / 2$, należy przedstawić probantkom propozycję profilaktycznego usunięcia jajników i jajowodów (a nawet macicy — ze względu na częste występowanie metachronicznych zachorowań na raka błony śluzowej macicy) w okresie pomiędzy 35 a 40 rokiem życia. Operacja taka zmniejsza ryzyko zachorowania na raka piersi wśród nosicielek mutacji o 50\%. Opisywana wcześniej redukcja ryzyka zachorowania na raka jajnika [8] została potwierdzona w tegorocznej publikacji międzynarodowego zespołu badawczego, który udowodnił nie tylko 80-procentowe zmniejszenie ryzyka zachorowania na raka jajnika, jajowodów i otrzewnej u nosicielek mutacji $B R C A 1$ poddanych ooforektomii, ale po raz pierwszy także 77-procentową redukcję śmiertelności z powodu tych nowotworów [9].

Począwszy od lat 90., kolejne publikacje potwierdzają skuteczność chemoprewencji w postaci stosowania przez nosicielki mutacji BRCA1/2 tamoksyfenu i raloksyfenu (zwłaszcza w grupie BRCA2+), jak również dla redukcji ryzyka nawrotu i raka drugiej piersi $[10,11]$. Skuteczne okazują się także inhibitory aromatazy u kobiet po ooforektomii [12], a przez cały czas sprawdzana jest przydatność chemoprewencyjna takich leków celowanych jak inhibitory PARP-1 [13].

W dużym przeglądzie na temat profilaktycznej mastektomii w prewencji raka piersi autorstwa Lostumbo i wsp. [14], w materiale pochodzącym z 39 badań obserwacyjnych, obejmujących dane 7384 kobiet, postawiono pytania:

- czy obustronna mastektomia u kobiet bez objawów choroby redukuje ryzyko zachorowania - grupa badana 3727 kobiet — średni czas obserwacji 14 mies.,

- czy mastektomia przeciwległej piersi poprawia wyniki leczenia - grupa badana 3657 kobiet,

- jaki jest odsetek raków, śmiertelność, czas wolny od nawrotu, chorobowość, konsekwencje psychosomatyczne. Dla oceny jakości życia grupę badaną stanowiły 1154 kobiety.

Analiza potwierdziła redukcję zachorowań na raka piersi, ale autorzy podkreślili liczne ograniczenia metodologiczne ocenianych badań. Podkreślono wzmiankowany wcześniej fakt braku gwarancji, że zachorowanie nie nastąpi, w związku z obecnością resztkowej tkanki gruczołowej poza obszarem resekcji. W grupie chorych bez rekonstrukcji $21 \%$ wymagało reoperacji, a $59 \%$ - w grupie z rekonstrukcją. Wskazaniem były: wczesne powikłania, problemy z implantem, względy estetyczne [15]. Dolegliwości fizyczne w postaci bólów, swędzenia i infekcji podawało $64 \%$ kobiet $[16,17]$. W ocenie jakości życia - mimo akceptacji podjętej decyzji — stwierdzano mniejsze zadowolenie z efektu kosmetycznego i gorsze postrzeganie samej siebie oraz $4 \%$ nieakceptowalnych efektów reoperacji u kobiet bez rekonstrukcji i 49\% u pa- 
cjentek po rekonstrukcji piersi [4]. Poziom satysfakcji korelował z aktywnym udziałem w dyskusji przed operacją [18]. Zmniejszenie lęku przed zachorowaniem może być modyfikowane wcześniejszymi przesadnymi wyobrażeniami o skali ryzyka. Autorzy podkreślają, że kluczem do podejmowania prawidłowej decyzji jest zrozumiała i kompletna informacja [19]. W odniesieniu do problemu mastektomii kontrlateralnej u chorych na raka piersi autorzy wielu badań podkreślali, że brak jest wystarczających dowodów na wpływ przeciwległej mastektomii na przebieg choroby i całkowite przeżycia [20]. Tylko 2,5\% zgonów spowodowane jest rakiem drugiej piersi [21]. Powszechnym jest fakt, że wyobrażenia o ryzyku zachorowania są wyolbrzymione ( $31 \%$ vs $7 \%$ w ciągu 10 lat) [20]. Wg danych SEER ryzyko zachorowania na raka drugiej piersi u chorych bez raka estrogeno-zależnego wynosi od 0,1 do $0,2 \%$ poniżej 50 roku życia, a powyżej 50 r. ż. jest jeszcze niższe. Wg rejestru genewskiego ryzyko wynosi średnio $0,3 \%$ rocznie [22].

Nie można jednak nie zauważać faktu, że liczba mastektomii przeciwległej piersi istotnie wzrosła w ostatnich latach [20]. Zalecenie Surgical Society of Oncology (SSO) dla mastektomii kontrlateralnej są następujące: wiek zachorowania $<40$ r. ż., stwierdzona mutacja $B R C A 1 / 2$, rak zrazikowy przedinwazyjny w przeciwległej piersi (LCIS), wielokrotne biopsje [23].

Mój dystans do profilaktycznej mastektomii jako rutynowego postępowania u kobiet wysokiego ryzyka zachorowania na raka piersi pogłębia postęp w dziedzinie onkologii, który oferuje nowe możliwości mniej inwazyjnego przeciwdziałania rozwojowi raka piersi. Analizując publikację Savage'a i wsp., należy spodziewać się nowych możliwości profilaktyki, wynikających z postępu wiedzy na temat roli BRCA1 w regulacji metabolizmu estrogenów i uszkodzeń DNA poprzez represję transkrypcji enzymów metabolizujących estrogeny, takich jak CYP1A1 [24].

Na pytanie postawione $w$ tytule debaty odpowiadam: $\mathrm{NIE}$, jeżeli nie zostały spełnione następujące warunki:

- nie stwierdzono mutacji genu BRCA1/2,

- nie stwierdzono kryteriów najwyższego lub wysokiego ryzyka zachorowania na raka piersi,

- nie przeprowadzono konsultacji genetycznej,

- nie zapewniono konsultacji psychologa,

- nie przedstawiono aspektu nieodwracalności procedury,

- nie wyjaśniono niedoskonałości efektu kosmetycznego po rekonstrukcji wobec piersi własnej,

- nie można zapewnić monitorowania skutków fizycznych i emocjonalnych przebytego zabiegu,

- kobieta nie ma wystarczającej motywacji do poddania się profilaktycznej mastektomii.

W mojej opinii profilaktyczna mastektomia, która wg danych z piśmiennictwa zmniejsza ryzyko zachorowania na raka piersi o $90 \%$, a u nosicielek mutacji genu BRCA1 nawet o 95\% [25], jest opcją dla ściśle zdefiniowanej pod względem ryzyka zachorowania grupy kobiet, pod warunkiem spełnienia wymogów wyszczególnionych powyżej. Wg zaleceń Narodowego Instytutu Raka w Stanach Zjednoczonych wskazaniem do profilaktycznej mastektomii są aktualnie: mutacja genu BRCA1 lub BRCA2 (a w modyfikacji z 21 sierpnia 2014 także genu $P A L B 2)$, silna agregacja raka piersi i/lub jajnika w rodzinie, wystąpienie raka jednej piersi u chorej z grupy wysokiego ryzyka zachorowania, rozpoznanie raka zrazikowego in situ u pacjentki z obciążonym wywiadem rodzinnym oraz napromienienie obszaru klatki piersiowej przed 30 rokiem życia (np. z powodu ziarnicy złośliwej), a także rozległe mikrozwapnienia w gęstym gruczole piersiowym poddawanym wielokrotnym biopsjom [26]. W Polsce trwa dyskusja zainicjowana przez Polskie Towarzystwo Chirurgii Onkologicznej nad sformułowaniem jednolitego dla wszystkich towarzystw naukowych stanowiska w kwestii mastektomii profilaktycznej.

W podsumowaniu stwierdzam, że:

1. Operacja usunięcia piersi u kobiet $z$ grupy wysokiego ryzyka zachorowania na raka piersi powinna $\mathrm{w}$ istocie nazywać się mastektomią zmniejszającą ryzyko, a nie stricte profilaktyczną.

2. Obiektywna ocena wartości inwazyjnej i nieodwracalnej procedury, jaką jest tzw. mastektomia profilaktyczna, wymaga badań randomizowanych, a z uwagi na brak możliwości ich przeprowadzenia — przynajmniej prospektywnych.

3. Kwalifikacja do „profilaktycznej mastektomii” powinna być wieloetapowa, zespołowa i obwarowana szeregiem warunków minimalizujących ryzyko podjęcia przez kobietę niekorzystnej, nieodwracalnej decyzji.

\section{Prof. dr hab. n. med. Sylwia Grodecka-Gazdecka}

Katedra i Klinika Onkologii

Uniwersytet Medyczny im. Karola Marcinkowskiego

ul. Szamarzewskiego 82/84, 60-569 Poznań

e-mail: sylwia.grodecka-gazdecka@skpp.edu.pl

\section{Piśmiennictwo}

1. Guillem JG, Wood WC, Moley JF i wsp. ASCO/SSO review of current role of risk-reducing surgery in common hereditary cancer syndromes. JClin Oncol 2006: 24: 4642-4660

2. Jassem J, Krzakowski M (red). Rak piersi. W: Zalecenia postępowania diagnostyczno-terapeutycznego w nowotworach złośliwych - $2013 \mathrm{r}$. Krzakowski M, Warzocha K (red). Gdańsk:VM Media Sp.z o.o. VM Group. 2013: 215-217.

3. Brandberg Y, Sandelin K, Erikson Si wsp. Psychological reactions, quality of life, and body image after bilateral prophylactic mastectomy in women at high risk for breast cancer: a prospective 1-year follow-up study. J Clin Oncol 2008; 26: 3943-3949.

4. Metcalfe KA, Esplen MJ, Goel V i wsp. Psychosocial functioning in women who have undergone bilateral prophylactic mastectomy. Psychooncology 2004; 13: 14-25.

5. Frost MH, Hoskin TL, Hartmann LC i wsp. Contralateral prophylactic mastectomy: long-term consistency of satisfaction and adverse effects and the significance of informed decision-making, quality of life, and personal traits. Ann Surg Oncol 2011; 18: 3110-3116.

6. Finch A, Metcalfe KA, Chiang JK i wsp. The impact of prophylactic salpingo-oophorectomy on menopausal symptoms and sexual function in women who carry a BRCA mutation. Gynecol Oncol 2011; 121: 163-168. 
7. Singletary $\mathrm{S}$. Techniques in surgery: therapeutic and prophylactic mastectomy. In: Harris J, Lippman M, Morrow M, Osborn C (eds.) Diseases of the breast. $3^{\text {rd }}$ ed. Philadelphia, PA: Lippincott Williams and Wilkins; 2004.

8. Reebeck TR, Friebel T, Wagner T i wsp. Effect of short-term hormone replacement therapy on breast cancer risk reduction after bilateral prophylactic oophorectomy in BRCA1 and BRCA2 mutation carriers: The PROSE Study Group. J Clin Oncol 2005; 23: 7804-7810.

9. Finch AP, Lubinski J, Møller P i wsp. Impact of oophorectomy on cancer incidence and mortality in women with a BRCA1 or BRCA2 mutation. J Clin Oncol 2014; 32: 1547-1553.

10. Fisher B, Constantino JP, Wickerham DL i wsp. Tamoxifen for the prevention of breast cancer: Current status of the National Surgical Adjuvant Breast and Bowel Project P-1 Study. J Natl Cancer Inst 2005; 97: 1652-1662.

11. Vogel VG, Constantino JP, Wickerham DL i wsp. Update of the National Surgical Adjuvant Breast and Bowel Project Study of Tamoxifen and Raloxifene (STAR) P-2 Trial: Preventing breast cancer. Cancer Prev Res 2010; 3: 696-706.

12. Goss PE, Ingle JN, Ales-Martinez JE i wsp. Exemestane for breast cancer prevention in postmenopausal women. New Engl J Med 2011; 364: 2381-2391.

13. Moyer VA; US Preventive Services Task Force. Medications to deorease the risk for breast cancer in women: recommendations from the U.S. reduction of primary U.S. Preventive Services Task Force recommendation statement. Ann Inter Med 2013 159: 698-708.

14. Lostumbo L, Carbine NE, Wallace J. Prophylactic mastectomy for the prevention of breast cancer. Cochrane Database Syst Rev 2010; 11: CD002748.

15. Zion SM, Slezak JM, Sellers TA i wsp. Reoperations after prophylactic mastectomy with or without implant reconstruction. Cancer 2003; 98: 2152-2160.
16. Gahm J, Wickman M, Brandberg Y. Bilateral prophylactic mastectomy in women with inheredit risk of breast cancer- prevalence of pain and discomfort, impact on sexuality, quality of life and feelings of regret two years after surgery. Breast 2010; 19: 462-469.

17. Barton MB, West CN, Liu IL i wsp. Complications following bilateral prophylactic mastectomy. J Natl Cancer Inst Monogr 2005; 35: 61-66.

18. Nekhlyudov L, Bower M, Herrinton LJ i wsp. Women's decision-making roles regarding contralateral prophylactic mastectomy. J Nat Cancer Inst. Monogr 2005; 35: 55-60.

19. Jin J.Women with breast cancer who opt for contralateral prophylactic mastectomy may overestimate future risk. JAMA 2013; 310: 1548-1551.

20. Katz SJ, Morrow M. Contralateral prophylactic mastectomy for breast cancer: addressing peace of mind. JAMA 2013: 310: 793-794.

21. Yao K, Stewart AK, Winchester DJ i wsp. Trends in contralateral prophylactic mastectomy for unilateral cancer: a report from the National Cancer Data Base, 1998-2007. Ann Surg Oncol 2010; 17: 2554-2562.

22. Bouchardy C, Benhamou S, Fioretta Gi wsp. Risk of second breast cancer according to estrogen receptor status and family history. Breast Cancer Res Treat 2011; 127: 233-241.

23. www.surgonc.org/practice-policy/position-statement-on-prophylactic mastectomy.

24. Savage KI, Matchett KB, Barros EM i wsp. BRCA1 deficiency exacerbates estrogen-induced DNA damage and genomic instability. Cancer Res 2014; 74: 2773-2784.

25. Domchek SM, Friebel TM, Singer CF i wsp. Association of risk-reducing surgery in BRCA1 or BRCA2 mutation carriers with cancer risk and mortality. JAMA 2010; 304: 967-975.

26. www. cancer.gov/cancertopics/factsheet/therapy/risk-reducing surgery. 